Available online at : http://journal.unj.ac.id/unj/index.php/gjik Gladi : Jurnal Ilmu Keolahragaan 09 (02) 2018, 86 - 95 Permalink/DOI: https://doi.org/10.21009/GJIK.092.02

\title{
UPAYA MENINGKATKAN KETERAMPILAN TEKNIK DASAR LOMPAT JAUH MELALUI METODE BERMAIN PADASISWA KELAS X 2 SMA LKMD SUKARAMAI KABUPATEN KAMPAR
}

\author{
Mimi Yulianti ${ }^{*}$, Frans Boy Stiur Jaya Zega ${ }^{2}$ Merlina Sari ${ }^{3}$ \\ Pendidikan Jasmani Kesehatan dan Rekreasi, Universitas Islam Riau \\ Jalan Kaharuddin Nasution No. 113 pekanbaru Riau \\ *Corresponding Author. Email: mimipenjas@edu.uir.ac.id
}

\begin{abstract}
Abstrak: Berdasarkan hasil observasi terhadap siswa kelas X 2 SMA LKMD Sukaramai Kabupaten Kampar peneliti melihat masih banyak siswa yang Kurang menguasaia teknik dasar lompat jauh dengan benar. Tujuan penelitian ini adalah untuk meningkatkan keterampilan teknik dasar lompat jauh pada siswa kelas X 2 SMA LKMD Sukaramai Kabupaten Kampar Jenis penelitian ini adalah penelitian tindakan kelas yang terdiri dari 2 variabel. Populasi dalam penelitian ini adalah seluruh siswa kelas X 2 SMA lkmd Sukaramai yang berjumlah 30 siswa. Teknik pengambilan sampel yang digunakan total sampling dengan berbagai pertimbangan dari peneliti dengan demikian jumlah sampel dalam penelitian ini berjumlah 30 siswa. Instrumen tes yang digunakan adalah unjuk kerja lompat jauh. Berdasarkan penelitian keterampikan teknik dasar lompat jauh dengan menggunakan metode bermain pada siswa kelas X 2 SMA LKMD Sukaramai Kabupatem Kampar, rata-rata kemampuan siswa pada tes awal dikategorikan Cukup Baik dengan persentase $65,41 \%$ pada siklus ke I teknik dasar lompat jauh dengaan menggunakan metode bermain memiliki peningkatan $80 \%$.
\end{abstract}

\section{Kata kunci : Keterampilan Teknik Dasar Lompat Jauh, Metode Bermain.}

Abstract : Pursuant to result of observation to class student of X 2 SMA LKMD Sukaramai Sub-Province Camphor researcher see still many Less student [of] elementary technique menguasaia [of] long jump truly. Target of this research is to uplift skill elementary technique [of] long jump [at] class student of X 2 SMA LKMD Sukaramai Sub-Province Camphor this Type Research [is] research of class action which consist of 2 variable. Population in this research [is] entire/all class student of X 2 SMA Sukaramai $1 \mathrm{kmd}$ amounting to 30 student. Technique intake of total used sampel [of] sampling with various consideration of researcher thereby the amount of sampel in this research amount to 30 student . instrument of Tes the used [is] unjuk work long jump Pursuant to research of elementary technique [of] long jump by using method play at [at] class student of X 2 SMA LKMD Sukaramai Kabupatem Camphor, mean ability of student [at] tes early categorized Good Enough with percentage $65,41 \%$ [at] cycle to elementary I technique [of] long jump of with use method play at to have improvement $80 \%$.

Keyword : Skill Of Elementary Technique [of] Long Jump, Method Play at 


\section{PENDAHULUAN}

Pendidikan jasmani sebagai komponen pendidikan secara keseluruhan telah diketahui oleh banyak kalangan. Namun, dalam pelaksanaannya pengajaran pendidikan jasmani berjalan belum efektif seperti apa yang diharapkan oleh semua orang. Pembelajaran pendidikan jasmani cenderung tradisional. Model pembelajaran pendidikan jasmani tidak harus terpusat pada guru tetapi pada siswa. Tahapan pembelajaran harus disesuaikan dengan perkembangan yang dimiliki oleh peserta didik yang menerimanya, isi dan urusan materi serta cara penyampaian harus disesuaikan sehingga menarik minat dan menyenangkan hati para peserta didik, sasaran pembelajaran ditujukan bukan hanya mengembangkan keterampilan olahraga, tetapi juga perkembangan pribadi anak seutuhnya.

Dalam undang-undang Republik Indonesia No.3 Tahun 2005 tentang sistem Keolahragaan Nasional Pasal 1 Ayat 11 : Olahraga pendidikan adalah pendidikan jasmani dan olahraga yang dilaksanakan sebagai proses pendidikan yang teratur dan berkelanjutan untuk memperoleh pengetahuan, kepribadian, ketereampilan, kesehatan dan kebugaran jasmani.

Berdasarkan undang-undang di atas olahraga pendidikan jasmani di lakukan untuk memperoleh pengetahuan, keterampilan, kesehatan dan kebugaran jasmani. Olahraga pendidikan jasmani juga dapat dilakukan oleh setiap orang maupun lembaga pendidikan untuk meningkatkan kesehatan, kemampuan berolahraga dan menumbuhkan sportifitas yang ada di dalam dirinya.

Pendidikan jasmani dan olahraga merupakan suatu bagian yang tidak terpisahkan dari pendidikan umum. Lewat program pendidikan jasmani dan olahraga dapat diupayakan peranan pendidikan jasmani dan olahraga untuk mengembangkan kepribadian individu. Sumbangan nyata dalam pendidikan jasmani dan olahraga adalah untuk mengembangkan keterampilan psikomotor. Karena itu posisi pendidikan jasmani dan olahraga menjadi unik, sebab berpeluang lebih banyak dari pada mata pelajaran lainnya untuk membina keterampilan. Hal ini sekaligus mengungkapkan kelebihan pendidikan 
jasmani dan olahraga dari pelajaranpelajaran lainnya.

Ada tiga hal penting yang bisa menjadi sumbangan unik dari pendidikan jasmani dan olahraga, yaitu :

(1) meningkatkan kebugaran jasmani dan kesehatan siswa, (2) meningkatkan terkuasainya keterampilan fisik yang kaya dan (3) meningkatkan pengertian siswa dalam prinsip-prinsip gerak serta bagaimana menerapkannya dalam praktek.

Secara umum manfaat pendidikan jasmani dan olahraga di sekolah mencakup sebagai berikut, adalah : (1) memenuhi kebutuhan anak akan gerak, (2) mengenalkan anak pada lingkungan dan potensi dirinya, (3) menanamkan dasar-dasar keterampilan yang berguna, (4) menyalurkan energi yang berlebihan dan (5) merupakan proses pendidikan secara serempak baik fisik,mental, maupun emosional.

Tujuan pendidikan jasmani adalah memberikan kesempatan kepada anak untuk mempelajari berbagai kegiatan yang membina sekaligus mengembangkan potensi anak, baik dalam aspek fisik, mental, sosial, emosional dan mmoral. Singkatnya pendidikan jasmani dan olahraga bertujuan untuk mengembangkan potensi setiap anaksetinggi-tingginya.

Dalam pendidikan jasmani banyak cabang olahraga yang terdapat di dalamnya, salah satunya adalah cabang olahraga atletik. Atletik adalah gabungan dari beberapa jenis olahraga yang sering di perlombakan, salah satunya adalah Lompat jauh. Lompat jauh merupakan suatu gerakan melompat ke depan atas dalam upaya membawa titik berat badan selama mungkin di udara ( melayang di udara ) yang di lakukan dengan cepat dan melakukan tolakan pada satu kaki untuk mencapai jarak yang sejauhjauhnya. Caranya yaitu dengan berlari sekuat mungkin lalu melakukan tolakkan tepat pada papan tolakan sekuat-kuatnya, lalu setelah itu gerakan melayang di udara serta menjaga keseimbangan tubuh saat mendarat di bak pasir yang telah disediakan agar dapat terjatuh dengan baik. Dalam proses pelaksanaan pembelajaran lompat jauh guru harus dapat mengajarkan keterampilan teknik dan strategi permainan suatu olahraga dengan benar, supaya para peserta didik dapat melakukannya dengan baik.

Keterampilan merupakan suatu karakteristik ataupun kemampuan umum dari seseorang yang berhubungan dengan pengetahuan dan keterampilan 
yang diwujudkan melalui tindakan. lompat jauh supaya peserta didik dapat

Keterampilan dasar mengajar pada dasarnya adalah berupa bentuk-bentuk Perilaku bersifat mendasar dan khususnya yang harus dimiliki oleh seorang guru sebagai modal awal untuk melaksanakan

tugas-tugas

pembelajarannya secara terencana dan profesional.

Teknik merupakan salah satu komponen prestasi olahraga yang merupakan ciri atau karakteristik suatu cabang olahraga dan oleh sebab itu harus dipersiapkan sebaik mungkin. Penguasaan teknik yang baik akan dapat menghemat dan mengoptimalkan kondisi fisik. Hal ini berarti penguasaan teknik yang baik akan dapat membantu menghemat penggunaan tenaga. Ini berati semakin baik penguasaan teknik suatu cabang olahraga maka semakin hemat dalam pemakaian tenaga yang di keluarkan.

Sebagai guru olahraga kita harus memiliki keterampilan dalam setiap bidang olahraga, terutama pada teknikteknik dasarnya, dengan memiliki keterampilan serta teknik dasar tersebut guru sangat diharapkan dapat memberikan contoh yang terbaik untuk para peserta didik dalam melakukan olahraga, terutama pada teknik dasar melakukan teknik dasar disetiap cabang olahraga dengan baik, sehingga peserta didik mampu mencapai tujuan yang diinginkan dalam proses pembelajaran teknik dasar lompat jauh.

\section{Adapun KKM ( Kriteria}

Ketuntasan Minimal ) yang harus di capai oleh siswa dalam pembelajaran pendidikan jasmani. Di sini peneliti mengetahui berapa nilai yang harus diperoleh oleh peserta didik untuk mendapatkan ketuntasan, menurut guru olahraga yang ada di SMA LKMD Sukaramai Kabupaten Kampar adalah siswa harus mencapai nilai 78 ( tujuh puluh delapan ), nilai ini berguna untuk mengantisipasi supaya nilai para peserta didik tidak terlalu rendah ketika mendapatkan persaingan di sekolahsekolah lain. Untuk mendapatkan nilai yang sudah ditentukan tersebut siswa dituntut agar bisa melakukan gerakan serta teknik dasar yang benar, terutama dalam pembelajaran lompat jauh yang akan peneliti lakukan, dalam melakukan lompat jauh siswa harus mencapai batas kejauhan yang telah di tentukan oleh guru olahraga.

Tetapi pada kenyataanya kejadian yang dilihat oleh peneliti pada saat proses pembelajaran di lapangan 
tidak seperti apa yang diharapkan. Di dalam melakukan pembelajaran lompat jauh peneliti melihat bahwa para peserta didik masih banyak yang belum memiliki keterampilan teknik dasar dalam lompat jauh, sehinnga lompatan yang dihasilka pada saat mendarat tidak sesuai dengan apa yang diharapkan oleh seorang guru.

Oleh karena itu peneliti ingin menigkatkan keterampilan teknik dasar lompat jauh pada peserta didik dengan menggunakan metode bermain, karena dengan metode barmain akan mampu membuat siswa senang mengikuti pembelajaran yang disampaikan oleh gurunya, tujuan dalam metode bermain ini adalah supaya siswa mampu menguasai teknik dasar lompat jauh dengan benar. Metode bermain yang di gunakan adalah metode yang mengutamakan teknik belajar supaya dapat mencapai sasaran pelajaran yang diinginkan.

Metode adalah cara berfikir secara baik untuk mencapai tujuan yang diinginkan, prinsip dan praktek-praktek pengajaran, metode juga dapat dikatakan sebagai suatu siasat atau usaha yang diberikan kepada para peserta didik untuk dapat mencapai pembelajaran yang diharapkan. Sedangkan bermain adalah sebuah fenomena atau aktivitas yang berkembang secara menyeluruh di dalam masyarakat, setiap orang bermain setiap harinya, meskipun begitu bermain di dalam ruang lingkup sekolah masih terasa terlarang.

Dalam penelitian ini metode bermain adalah suatu aktivitas yang diberikan kepada peserta didik, aktivitas tersebut adalah aktivitas yang membuat mereka senang dan tidak membosankan, meskipun begitu aktivitas atau metode ini memiliki hubungan untuk meningkatkan keterampilan peserta didik dalam melakukan lompat jauh. Untuk melakukan metode ini peneliti menggunakan bahan yang aman dan mudah diperoleh yaitu adalah kerdus yang terbuat dari bahan yang tidak terlalu keras.

Dalam observasi yang telah dilakukan, dapat diketahui bahwa masih banyak siswa yang belum bisa melakukan pembelajaran lompat jauh secara maksimal. Adapun masalah yang penulis ketahiu yaitu : (1)siswa kurang maksimal dalam melakukan lompat jauh, hal ini di sebabkan karena masih banyak siswa yang belum menguasai teknik dasar lokpat jauh, (2) siswa kurang serius dan merasa malu dalam melakukan pembelajaran lompat jauh, 
sehingga masih banyak yang kurang tepat dalam melakukan tolakan, (3) siswa masih ragu-ragu dalam melakukan lompat jauh, karena prasarana yang kurang mendukung.

\section{METODE PENELITIAN}

Penelitian ini adalah penelitian tindakan kelas yaitu, penelitian yang dilakukan dalam kelas dengan tujuan untuk meningkatkan keterampilan teknik dasar lompat jauh dengan metode bermain. Menurut Arikunto (2015 : 124 ) menyatakan bahwa penelitian tindak kelas (PTK) adalah penelitian yang dilakukan oleh guru, dengan tujuan memperbaiki mutu praktik pembelajaran di kelasnya. PTK berfokus pada proses belajar mengajar yang terjadi di kelas, di lakukan pada situasi alami. Penelitien ini dilaksanakan pada siswa kelas X 2 SMA LKMD Sukaramai Kabupaten Kampar Tahun ajaran 2017-2018. Jumlah subjek penelitian 30 orang dimana penelitian ini dilakukan sebanyak 1 siklus, dalam satu siklus ini terdapat 2 kali pertemuan. Prosedur penelitian ini terdiri dari tahapan penelitian, yaitu adalah rencana tindakan, pelaksanaan tindakan, observasi / evaluasi, refleksi. Penelitian ini dilaksanakan pada hari Rabu 14 Februari 2018 dan hari rabu tanggal 21
Februari 2018. Teknik pengumpulan data observasi belajar yaitu dengan 1 orang observer dari Guru Penjaskes SMA LKMD Sukaramai Kabupaten Kampar.

\section{HASIL DAN PEMBAHASAN}

\section{Hasil Tes Awal}

Hasil tes awal merupkan hasil dari penilaian Keterampilan Teknik Dasar Lompat Jauh Melalui Metode Bermain Pada Siswa Kelas X 2 SMA LKMD Sukaramai Kabupaten Kampar sebelum di terapkannya metode bermain. Tujuannya untuk mengetahui perbedaan hasil pembelajaran sebelum melakukan metode bernain dengan hasil pembelajaran setelah melakukan metode bermain. Unuk melihat keterangan yag lebih jelas dapat dilihat pada hisogram di bawah ini.

Pada kategori Sangat Baik diperoleh oleh 4 orang siswa dengan persentase 13,3\%, pada kategori Baik diperoleh oleh 7 orang siswa dengan persentase 23.33\%, pada kategori Cukup Baik di peroleh oleh 14 orang siswa dengan persentase 46,66 \%, pada kategori Kurang Baik diperoleh oleh 4 orang siswa dengan persentase $13.33 \%$, dan pada kategori Tidak Baik diperoleh oleh 1 orang siswa dengan kategori 3,33\%. 
Dari tabel di bawah ini kita juga dapat melihat rata-rata nilai tes awal yang didapatkan oleh peserta didik sebelum metode bermain di lakukan yaitu 65,41 atau dalam kategori "Cukup Baik".

Tabel 1. Analisis Kemampuan Teknik Dasar Lompat Jauh Sebelum Siklus

\begin{tabular}{ccccc}
\hline No & Inteerval & Kategori & Jumlah & persentase \\
\hline 1 & 10 sd 29 & Tidak Baik & 1 & $3,33 \%$ \\
2 & 30 sd 49 & Kurang Baik & 4 & $13,33 \%$ \\
3 & 50 sd 69 & Cukup Baik & 14 & $46,66 \%$ \\
4 & 70 sd 89 & Baik & 7 & $23,33 \%$ \\
5 & 90 sd 100 & Sangat Baik & 4 & $13,33 \%$ \\
& Jumlah & 30 & $100 \%$ \\
Rata - rata & Kategori & \multicolumn{2}{c}{ Cuk,41\% Baik } \\
\hline
\end{tabular}

Tabel 2. Analisis Teknik Dasar Lompat Jauh Setelah Siklus

\begin{tabular}{|c|c|c|c|c|}
\hline No & Interval & Kategori & Jumlah & Persentase \\
\hline 1 & $10 \mathrm{sd} 29$ & Tidak Baik & 0 & $0,0 \%$ \\
\hline 2 & $30 \mathrm{sd} 49$ & Kurang Baik & 0 & $0,0 \%$ \\
\hline 3 & $50 \mathrm{sd} 69$ & Cukup Baik & 6 & $20 \%$ \\
\hline 4 & 70 sd 89 & Baik & 20 & $66,66 \%$ \\
\hline 5 & $90 \mathrm{sd} 100$ & Sangat Baik & 4 & $13,33 \%$ \\
\hline \multicolumn{3}{|c|}{ Jumlah } & 30 & $100 \%$ \\
\hline \multicolumn{3}{|c|}{ Rata-rata } & \multicolumn{2}{|c|}{$80 \%$} \\
\hline \multicolumn{3}{|c|}{ Kategori } & \multicolumn{2}{|c|}{ Baik } \\
\hline
\end{tabular}

Berdasarkan tabel di atas, maka analisis terhadap kemampuan siswa setelah siklus Iadalah sebagai berikut : 1. Interval nilai $90 \mathrm{sd} 100$ adalah kategori "Sangat Baik" diperoleh 4 orang siswa. 2. Interval nilai $70 \mathrm{sd} 89$ adalaha kategori "Baik” diperoleh 20 orang siswa. 3. Interval nilai 50 sd 69 adalah kategori "Cukup Baik" diperoleh 6 orang siswa. 4. Interval nilai 30 sd 49 adalah kategori "Kurang Baik" Tidak diporoleh siswa. 5. Interval 10 sd 29 adalah kategori "Tidak Baik" tidak diperoleh siswa.

Selanjutnya dari tabel juga dapat dilihap rata-rata nilai yang diperoleh oleh peserta didik setelah siklus I adalah 80 atau dapat dikategorikan "Baik" . berdasarkan tabel dan uraian di atas maka dapat dikatakan bahwa rata-rata kempuan teknik dasar lompat jauh melalui metede bermain siswa SMA LKMD sukaramai kabupten kampar sudah ada peningkatan ataupun lebih baik dari 
pada sebelum diterapkannya metode. Pernyataan tersebut dapat dilihat pada tabel perbandingan berikut :

Dari tabel di bawah terlihat bahwa rata-rata kemampuan siswa sebelum tindakan hanya memperoleh nilai rata-rata 65,41 dengan 4 orang siswa memperoleh kategori sangat baik $(13,33 \%), 7$ orang siswa memperoleh kategori baik $(23,33 \%)$, 14 orang siswa memperoleh kategori cukup baik (46,66\%), 4 orang siswa memperoleh kurang baik (13,33\%) dan 1 orang siswa memperoleh kategori tidak baik $(3,33 \%)$.

Tabel 3. Perbandingan Kemampuan Teknik Dasar Lompat jauh pada siswa kelas X 2 SMA LKMD Sukaramai Kabupaten Kampar

\begin{tabular}{|c|c|c|c|c|c|c|}
\hline \multirow[b]{2}{*}{ No } & \multirow[b]{2}{*}{ Interval } & \multirow[b]{2}{*}{ Kategori } & \multicolumn{2}{|c|}{ Sebelum Siklus } & \multicolumn{2}{|c|}{ Siklus I } \\
\hline & & & Jumlah & Persentase & Jumlah & Persentase \\
\hline 1 & $10 \mathrm{sd} 29$ & Tidak baik & 1 & $3,33 \%$ & 0 & $0,0 \%$ \\
\hline 2 & 30 sd 49 & Kurang baik & 4 & $13,33 \%$ & 0 & 0,0 \\
\hline 3 & $50 \mathrm{~s}$ & Cukı & 14 & & 6 & \\
\hline \multirow[t]{5}{*}{4} & 70 sd 89 & & 7 & & 20 & $66,66 \%$ \\
\hline & & Sangat baik & 4 & & 4 & $13,33 \%$ \\
\hline & \multicolumn{2}{|c|}{ Jumlah } & 30 & 100 & 30 & $100 \%$ \\
\hline & \multicolumn{2}{|c|}{ Rata-rata } & \multicolumn{2}{|c|}{$65.41 \%$} & \multicolumn{2}{|c|}{$80 \%$} \\
\hline & \multicolumn{2}{|c|}{ Kategori } & \multicolumn{2}{|c|}{ Cukup Baik } & \\
\hline \multicolumn{5}{|c|}{ Sedangkan setelah melakukan siklus $\quad \mathbf{P}=\mathbf{8 0}$} & & \\
\hline \multirow{2}{*}{\multicolumn{4}{|c|}{$\begin{array}{l}\text { I } \text { Siswa memperoleh nilai rata-rata } \\
80 \text { dengan } 4 \text { orang } \text { siswa }\end{array}$}} & \multirow{3}{*}{\multicolumn{3}{|c|}{$\begin{array}{l}\text { Dapat diketahui bahwa } \\
\text { indikator keberhasilan yang dicapai } \\
\text { pada sklus I adalah } 80 \% \text {. Pernyataan }\end{array}$}} \\
\hline & & & & & & \\
\hline \multirow{2}{*}{\multicolumn{4}{|c|}{ 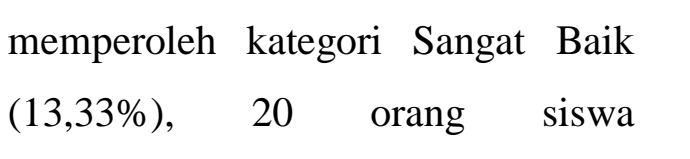 }} & & & \\
\hline & & & & \multicolumn{3}{|c|}{$\begin{array}{l}\text { pada sklus I adalah } 80 \% \text {. Pernyataan } \\
\text { tersebut membuktikan bahwa }\end{array}$} \\
\hline \multicolumn{4}{|c|}{ memperoleh kategori Baik $(66,66 \%)$} & \multirow{2}{*}{\multicolumn{3}{|c|}{$\begin{array}{l}\text { indikator keberhasilan telah tercapai } \\
\text { yaitu adalah } 80 \% \text {, maka Penelitian }\end{array}$}} \\
\hline \multicolumn{4}{|c|}{ dan 6 orang siswa memperoleh } & & & \\
\hline \multirow{2}{*}{\multicolumn{4}{|c|}{$\begin{array}{l}\text { kategori Cukup Baik }(20 \%) \text {. } \\
\text { Sehingga indikator yang tercapai } \\
\text { pada siklus I ini adalah : } \mathbf{P}=\end{array}$}} & \multirow{2}{*}{\multicolumn{3}{|c|}{$\begin{array}{l}\text { Tindak Kelas ini tidak perlu lagi } \\
\text { untuk dilanjutkan karena peserta } \\
\text { didik telah mencapai keberhassilan }\end{array}$}} \\
\hline & & & & & & \\
\hline \multicolumn{4}{|c|}{$\frac{\mathbf{F}}{\mathbf{N}} \mathbf{X} \mathbf{1 0 0} \%$ maka } & \multicolumn{3}{|c|}{ yang diharapkan. } \\
\hline \multicolumn{4}{|c|}{$P=\frac{24}{30} x 100 \%$} & \multicolumn{3}{|c|}{$\begin{array}{l}\text { Melihat perbandingan hasil } \\
\text { yang dilakukan siswa pada data awal }\end{array}$} \\
\hline
\end{tabular}


dan data setelah siklus I, pada data awal unjuk kerja lompat jauh siswa memperoleh nilai dengan persentase $65,41 \%$. Sedangkan pada siklus I siswa memperoleh nilai dengan persentase $80 \%$. Jadi peningkatan atau kenaikan hasil belajar siswa adalah $14,59 \%$.

Analisis keterampilan teknik dasar lompat jauh melalui metode bermain pada siswa kelas $X 2$ SMA LKMD Sukaramai Kabupaten Kampar pada tes awal. Berdasakan hasil yang diperoleh pada tes kemampuan aawal dari 30 siswa. Siawa pada nilai interval antara 90 sds 100 yang termasuk kategori sangat baik adalah 4 orang siswa dengan persentase $13,33 \%$ Siswa pada nilai inteval antara 70 sd 89 yang termasuk kategori baik adalah 7 orang siswa dengan persentase 23,33 \%. siswa pada nilai interval 50 sd 69 yang termasuk kategori cuku baik adalah 14 orang dengan persentase 46,66. Siswa pada nilai interval 30 sd 49 termasuk kategori kurang baik aadalah 4 orang dengan persentase $13,33 \%$ dan siswa pada nilai interval 10 sd 29 termasuk kategori tidak baik adalah 1 orang dengan persentase $3,33 \%$.

Analisis data kemampuan keterampilan teknik dasar lompat jauh melalui metode bermain pada siswa kelas $X$ sukaramai Kabupaten Kampar pada siklus I

Berdasarkan hasil yang di peroleh pada tes kemampuan siklus I dari 30 siswa pada interval 90 sd 100 yang termasuk kategori sangat baik adalah 4 orang siswa dengan persentase $13,33 \%$, pada interval 70 sd 89 yang termasuk kategori baik adalah 20 orang siswa dengan persentase $66,66 \%$, pada interval 50 sd 69 yang termasuk kategori cukup baik adalah 6 orang siswa dengan persentase $20 \%$, pada interval $30 \mathrm{sd}$ 49 tidak diperoleh siswa dan pada interval 10 sd 29 tidak diperoleh siswa.

Hasil analisis ini menunjukan bahwa kemampuan teknik dasar lompat jauh melalui metode bermain siswa kelas X 2 SMA LKMD Sukaramai Kanupaten Kampar pada siklus I rata-rata mendapatkan nilai 80 dengan 4 orang siswa $(13,33 \%)$ 
dan 20 orang siswa ( 66,66 \%) yang tuntas. Dengan kondisi tersebut maka dapat dikatakan bahwa keterampilan teknik dasar lompat jauh yang dilakukan oleh siswa SMA LKMD Sukaramai sudah memenuhi ketuntasan dan penelitian inipun tidak perlu dilanjutkan lagi.

\section{KESIMPULAN}

Dari penilaian dan analisa data di atas maka peneliti menyimpulkan bahwa melalui metode bermain melompati kerdus dapat meningkatkan keterampilan teknik dasar lompat jauh. Hal ini dikatakan sesuai dengan bukti yang dilihat oleh peneliti di lapangan, yaitu terdapat peningkatan setelah melakukan siklus I perbandingan tersebut dapat dilihat pada lembar penilaian unjuk kerja lompat jauh sebelum siklus dan setelah siklus I. Melompati kerdus yang dilakukan oleh siswa secara bergantian dan harus mendapat semua giliran yang telah di tentukan oleh peneliti.

\section{DAFTAR PUSTAKA}

Adi, Winendra, dkk. 2008. Seri Olahraga Atletik Lari, Lompat dan Lempar. Yogyakarta. Pustaka Insan Madani
Arikunto, suharsimi, dkk. 2015. Penelitian Tindak Kelas. Jakarta: Rineka Cipta.

Bagus, Pratama, Aditya. 2012. Kamus Lengkap Bahasa Indonesia. Surabaya.Pustaka Media.

Cristanto, Irfan. 2013. Pengaruh Modifikasi Permainan Terhadap Hasil Belajar Lompat Jauh Gaya Walking In The Air. Vol.01. No.02. Tahun 2013. 372- 376.

Nurmai, Erizal. 2011. Athletic, Dasar-dasar Atletik : Padang..

Hamalik, Oemar. 2014. Kurikulum dan Pembelajaran. Jakarta. Bumi Aksara.

Paturusi, Achmad. 2012. Manajemen Pendidikan Jasmani dan Olahraga. Jakarta. Rineka Cipta.

Perdana, muhammad Febrianto. 2016. Penerapan Metode Bermain Lompat Gembira Untuk Meningkatkan Keterampilan Gerak Lompat Jauh Gaya Jongkok Pada Siswa Kelas VII D Madrasah Tsanawiah. Vol.04. No.01 Tahun 2016. 412-416.

Sahabuddin. 2012. Pengeruh Model Pembelajaran Pendidikan Jasmani Dengan Pendekatan Bermain Terhadap Peningkatan Kesegaran Jasmani Terhadap Siswi SMA N1 Pinrang. Vol.6. No. 2 Oktober 2012. 
Gladi Jurnal Ilmu Keolahragaan, 09 (2), Oktober - 95

Mimi Yulianti, Frans Boy Stiur Jaya Zega, Merlina Sari

Suardika, I Putu, dkk. 2014.

Dasar. Jakarta. Kencana

Penerapan Pembelajaran

Prenada Media.

Kooperatif TGT Untuk

Meningkatkan Aktivitas dan

Hasil Belajar Lompat Jauh.

Vol.01.Tahun 2014.

Sugiyono. 2015. Metode Penelitian

Pendidikan Pendekatan

Kuantitatif,Kualitatif Bandung.

Alfabeta.

Susanto, Ahmad. 2013. Teori Belajar

Pembelajaran Di Sekolah

Kementrian Pendidikan dan

Kebudayaan Republik

Indonesia. 2016. Pendidikan

Jasmani Olahraga Dan

Kesehatan. Jakarta

Sidik Zafar, Didik. 2010. Mengajar dan Melatih Atletik. Bandung. Remaja

Rosdakarya. 